\title{
THE USE OF FLASHCARDS FOR TEACHING WRITING TO ENGLISH YOUNG LEARNERS (EYL)
}

\author{
Paramita Kusumawardhani
}

Program of English Department, Faculty of Communication and Language, University of Bina Sarana Informatika, Jl.Kamal Raya No. 18, Outer Ringroad, Cengkareng Jakarta Barat paramita.pmi@bsi.ac.id

\begin{abstract}
The aim of this research is to know about the use of flashcards in improving the English Young Learners' writing skills. English has four skills to be learned; they are listening, speaking, reading, and writing where writing skill is the most difficult skill to be taught and learned. Flashcard is one of the ways to improve the learners' skill, especially EYL writing skill. The participants of this research are English Young Learners (EYL) of the English Course at Gading Serpong, Tangerang. Classroom Action Research (CAR) was used as the method of the research and the English Young Learners' (EYL) story papers were used as the instruments of the research. The results of the research are: (1) most learners are excited when they are asked to see the colorful flashcards; (2) learners who have good writing skill could make the story by completing the missing words and answer the questions then arrange the answer sentences well; and (3) learners who are not really master in writing, get some difficulties not only in completing the missing words but also answering then arranging the answer sentences well.
\end{abstract}

Keywords: flashcard, writing skill, English Young Learners (EYL)

\begin{abstract}
ABSTRAK
Tujuan dari penelitian ini adalah untuk mengetahui penggunaan flashcards dalam meningkatkan keterampilan menulis para pembelajar muda Bahasa Inggris. Bahasa Inggris memiliki empat keterampilan yang dapat dipelajari, yaitu: keterampilan menyimak, berbicara, membaca dan menulis, dimana keterampilan menulis adalah keterampilan yang paling sulit untuk diajarkan dan dipelajari. Flashcard adalah salah satu cara untuk meningkatkan keterampilan, khususnya keterampilan menulis. Partisipan dari penelitian ini adalah para pembelajar muda bahasa Inggris di salah satu tempat kursus bahasa Inggris di Gading Serpong, Tangerang. Metode penelitian tindakan kelas adalah metode yang digunakan dalam penelitian ini dan kertas-kertas latihan para pembelajar muda bahasa Inggris tersebut digunakan sebagai instrumen penelitian. Hasil dari penelitian ini, yaitu: (1) sebagian besar pembelajar sangat senang ketika diperlihatkan flashcards berwarna-warni; (2) para pembelajar yang memiliki keterampilan menulis yang baik dapat membuat cerita dengan melengkapi kata-kata yang hilang dan menjawab pertanyaan-pertanyaan lalu menyusun kalimatkalimat jawaban tersebut dengan baik; dan (3) para pembelajar yang tidak begitu menguasai keterampilan menulis, menghadapi beberapa kesulitan tidak hanya dalam melengkapi kata-kata yang hilang tetapi juga dalam menjawab lalu menyusun kalimatkalimat jawaban dengan baik.
\end{abstract}

Kata Kunci: flashcard, kemampuan menulis, para pembelajar muda Bahasa Inggris 


\section{INTRODUCTION}

English has become international language which is used in every aspect in life, such as entertainment, business, education, and so forth. Because of that reason, now many people study English. English has four skills which have to be learned and mastered, they are: listening, speaking, reading, and writing. Writing is the most difficult skill in learning English. Writing becomes difficult because what we say is different with what we write.

There are some factors which make English, especially writing skill looks difficult. Writing skill is related to vocabulary, spelling, grammar, punctuation, and so on. Writing also relates to some factors, such as suffixes, prefixes, infixes, ablaut, and reduplication. It is also related to some linguistics branches, such as Morphology, Syntax, Semantics, Sociolinguistics, and Psycholinguistics. Thus, before started writing, the learners should master the theories of writing to avoid the mistakes that will be made.

Lately, there are many ways to improve English skill, especially writing. The teachers or educators should find appropriate method to teach and to improve the learners', especially English Young Learners' (EYL) writing skill. Flashcard is one of the teaching media to teach and to improve the learners', especially EYL writing skill. Flashcard can be used to teach and to improve not only the learners' listening, speaking, reading and writing but also the learners' vocabulary, pronunciation, grammar, spelling, and so forth. It is used to teach and to improve the EYL writing skill because it is usually colorful which can attract the EYL's attention. Flashcard is also attractive as there are many series of the flashcards which can be used to teach and to improve the EYL's writing skill.

Flashcards play a special role in teaching writing because they are characterized by originality and eagerness. Teaching writing by using flashcards can also be fun because usually the flashcards are colorful so the flashcards themselves can attract the learners' attention. There are some types of flashcards, they are: imperative and implementation cards, question and answer cards, games cards that are used in box games, theoretical game or names game and then the flashcards.

Teaching writing to EYL needs special approach as EYL also has special characteristics. Teaching writing to EYL needs step-by-step process. They need to be taught through step-by-step process as the EYL still does not know how to express the idea well. So, the use of flashcard is one way that can be used to teach and to improve the EYL's writing skill.

Flashcard is a picture card that comes with the words introduced by Glenn Doman, a brain surgeon from Philadelphia, Pennsylvania. The pictures on the flashcards grouped in several series: animals, fruits, colors, shapes, alphabet, numbers, professions and so on. The cards are played by children and shown to rapidly read out for each card. The cards are usually displayed with a variety of attractive colors because children prefer objects.

Flashcard is one of the simplest and effective teaching materials for teaching EYL due to the fact that flashcards are full colored pictures which attractive for EYL. Flashcard consists of devices that are grouped by type or class, for example, groups of pictures of food, fruits, vegetables, household items, transportation, and apparel in addition. Flashcards are a set of cards bearing information, such as words, pictures, or numbers, on either or both sides, used in classroom drills or in private study (Teng and $\mathrm{He}, 2015)$.

$\mathrm{He}$ also mentioned that through using flashcards, teachers can help students improve autonomy in three ways: first, by instructing students how to select words. They can self-select words for 
study, which is crucial for learners because EFL students tend to encounter more words than they could possibly memorize at short notice. Second, flashcards can give learners choices of what information to include for a new word. After being instructed as to the different kinds of information, e.g., synonyms, antonyms, collocations, example sentences, pictures, that are available, students may be able to choose for themselves which piece of information is appropriate for their learning. Third, flashcards can be used to facilitate memorization by way of spaced repetition. The process of creating flashcards may exercise the mental processes of active recall. It may also present different ways for students to monitor and evaluate their learning processes.

Flashcard can also be used to teach and to improve the learners, especially EYL English skill as it is difficult to make engagement with YL in English teaching and learning because EYL have different mood, self-motivation, and self-confidence which influenced to the willingness in grasping the lesson.

The characteristic of flashcards is a picture that accompanied the words as a caption. The goal of the method is to train the right brain's ability to remember images and words, so that the vocabulary and reading skills that the children can be trained and improved at an early age. In fact, in infants, the method of flashcards will help stimulate the development of visualization that can enhance the power of imagination, curiosity, concentration, and ability to pay attention to a particular object. Along with its development, flashcards are now easily found in book stores at affordable prices. This will make it easier for every child to learn English at home and at school.

Susilana and Riyana (2009) stated that flashcard is a teaching tool which is made from card and consists of pictures with the size of $25 \times 30 \mathrm{~cm}$. The pictures are made with hand, photo or by using available pictures then stick them on the cards. Meanwhile, Arsyad (2011) has different opinions about flashcard. He said that flashcard usually appears with the size of $8 \times 12 \mathrm{~cm}$ or it is made based on the size of the classroom. Then those cards consist of pictures of animals, things, fruits, and so forth. Izzan (2009) stated that flashcard is a teaching tool which is made from the newspaper with the size of $18 \mathrm{x}$ $16 \mathrm{~cm}$ which has attractive pictures, words or sentences. Permadi and Suryana (2000) explained that flashcard is one of educative games in cards which contains pictures and words made to improve the learners' aspects.

Flashcards can be bright and colorful and make a real impact on visual learners. These are simply cards that display the written word. Flashcards are really handy resources to have and can be useful at every stage of the class. They are great tools to present, to practice and to recycle vocabulary and when students become familiar with the activities used in class, they can be given out to earlyfinishers to use in small groups.

There are also some benefits of using flashcard to teach and to improve the learners', especially EYL skill. The benefits are:

1. Reading

By using flashcards, love of children in reading increases, because their new series of words and new vocabulary knowledge also increase. Thus, a positive attitude towards children's books as resources can be developed. In accordance with the development of age, each child will experience several stages in the ability to read as follows: stage magic, selfconcept stage, the stage of the reader, take-off phase, and independent stages.

2. Listening

By using flashcards, children will facilitate the mastery of English listening because children are socialized and are introduced to 
pronunciation of a word in the English language correctly. Therefore, the child will more easily understand what the other person means.

3. Speaking

With a variety of new vocabulary and vocabulary are more derived from the introduction of flashcards, then automatically, the child will be easier to speak the English language. Children increasingly understand that communication is done verbally though begins with children's language simple.

4. Writing

By using flashcards, children will be easier to increase the ability they wrote. In addition, children will understand the concept that writing can be used as a medium to communicate. In accordance with the development of age, each child will experience writing abilities as stages: the stages of strike out and scratch, linear repetition, random letters, phonetic, phase transitions spelling and conventional spelling.

The four languages skills and components should be known by the learners or students in learning English. It is very important for the learners or students, especially EYL to be able to write in English for their future life. Informal writing can be used as a start to learn to write, and flashcard can be used to accommodate this.

Writing is the most difficult part in English subject as what it is said different from what it is written. Ron and Ardnt (2011) stated that writing is far from being a simple matter of transcribing language into written symbols; it is a thinking process in its right. Therefore, before the learners starting to write an English composition, they should master the English pattern correctly.

Writing is one of the skills in learning English. Writing skill is related to the learners' competence. It emphasizes on writing ability such as the production of a variety of genres and rhetorical features, but also including language-specific abilities like the use of a range of vocabulary and syntactic structures. Some learners, especially EYL have difficulties to express their ideas through writing. The difficulties are sometimes about choosing the topic of their writing. Therefore, they need some help to find out the inspiration about what to write so they can express their ideas through writing easily. A good technique in writing should be chosen to ease the teaching learning process.

Writing can be said well if it can give information or messages clearly and creates effective verbal dialogue to readers. It aims to give point of view of the ideas in text where it organizes in different way of writing such as narration, description, exposition, and argumentation. When students write a paragraph, they try to explore what they are thinking in mind, and they also concern with the language, meaning, and the structural of context related to English language acquisition as second or foreign language.

Writing must be related to the content; the language and grammatical rule are related to writing. They should be done well in order to avoid a misunderstanding so the learners have to use correct sentences by creating a well written text and giving attention to the arrangement of words their composition to express their idea and to give the value of the writing to readers.

Writing is seen as a product constructed from the writer's command of grammatical and lexical knowledge, and writing development is considered to be the result of imitating and manipulating models provided by the teacher. For many who adopt this view, writing is regarded as an extension of grammar-a means of reinforcing language patterns through habit formation and testing learners' ability to produce well-formed sentences. 
Developing writing is related to the writer's knowledge of language and writing exposure, and writing process is the way the writers give their ideas and messages to readers in the form of text. Various ways of writing such as narration, description, classification, comparison and contrast, argumentation and so on can be used to express or share the writers' ideas. Here are some ways to express and share the writers' ideas, (1) Narration. It is a basic writing strategy for presenting past event or activities. It can be used for a variety of purposes such as to illustrate and to support ideas with anecdotes, to entertain readers with revealing stories, to analyze causes and possible effects with scenarios, and to explain procedures with process narrative; (2) Description. It is a strategy used to create a dominant impression. For example, describing a place in order to set a scene and to make readers aware of its atmosphere and to describe people to show a kind of person's performance; (3) Classification. It aims to classify number of items or ideas into a small number of classes. In a classification of paragraph, it is important to set up adequate categories and to define what goes into categories; (4) Comparison and contrast are to compare similar aspects or to contrast different aspects of two subjects, people or things, and (5) Argumentation. It is to argue ideas or opinion by giving some argues to proof the concept or research. A good paragraph must give readers complete information and unified by a controlling idea. It is organized form and can be understood what the paragraph is going to be about.

There is a phenomenon in learning English. Learning English has started in the early age. It has happened since the second half of the century. It is also happened because now English is used in order to face the global demand which its emphasis is on the need for communication skills.

The information process between EYL and adult is different. Children, start from an early age, begin to sort out words involving concrete subjects. It happens when EYL study about vocabulary. They need objects which they can see or handle. EYL do not comprehend abstract subjects such as grammar. Bourke (2006) notes that young learners do not have a concept of ideas such as parts of speech, discourse or phonology. Cameron (2003) says that some differences are immediately obvious: children are more enthusiastic and lively as learners. They want to please the teacher rather than peer-groups. They will have a go at an activity even when they do not quite understand why or how. However, they also lose interest more quickly and are less able to keep themselves motivated on tasks they find difficult. Children do not find it as easy to use language to talk about language; in other words, they do not have the same access as older learners to meta-language that teachers can use to explain about grammar or discourse. Children often seem embarrassed than adults at talking in a new language, and their lack inhibition seems to help them get a more native-like accent.

EYL's characteristics are necessary to be known and understood by EYL's teachers. It is done because it will influence many aspects in teaching English to EYL. The aspects are: teaching style, methods, teaching materials, lesson plan and the way of getting along with them. The aspects become important to be understood by EYL's teachers as EYL usually want to know about everything, as Pinter (2006) says that young learners have a great curiosity to try new things and to explore concrete to abstract things. Harmer (2001) also explains that young learners get their understanding not only from explanation but also from what they see and hear, learn when they have a chance to touch and interact with (experience it).

Juhana (2014) states that teaching English as a foreign language to young learners needs special approach since 
young learners have special characteristics. It is stated that the improvement of abilities to learn foreign language is started from the early age. Teaching EYL needs interesting materials. It is done in order to get the EYLs' attention as EYLs' knowledge, especially about language, is limited. Slattery and Willis (2001) affirm that young learners have a quite short attention span and are easy to get bored. So, comprehending the EYL's characteristics and selecting the suitable materials are important in order to be successful in teaching EYL.

\section{METHOD}

The participants of this research were the English Young Learners (EYL), which the age between 10-12 years old, from one of the English Courses at Gading Serpong, Tangerang. The data for this research was taken from the learners' story papers and there were about 5 pieces of the learners' story papers used as the samples. The method used in this research is Classroom Action Research (CAR). According to Wallace (1998), Classroom Action Research (CAR) is a type of classroom research carried out by the teacher in order to solve problems or to find answer toward context-specific issues. It means that before implementing the Classroom Action Research (CAR), the researcher or the teacher needs to identify any problems real found in the classroom before implementing the CAR. Recognizing, completing the missing words, answering the questions then arranging the answer sentences were done as the procedures of the research. They were carried out in order to know about the effectiveness of using flashcards for teaching writing to English Young Learners (EYL).

\section{RESULTS AND DISCUSSION}

Some findings were found in the research. The findings then were interpreted in order to give clear explanations related to the topic which was being discussed. The findings were also used to teach and to improve the learners', especially EYL's English writing skill. Based on the results which were taken from the learners' writing, it can be seen that the learners could make the story well as they were given the questions guidance. The questions guidance was related to the flashcard. The learners were asked to recognize the flashcard given then the learners were given and asked to complete the sentences by using the words given in the box.

The followings are the EYL's writing related to the flashcard.

\section{In the Kitchen}

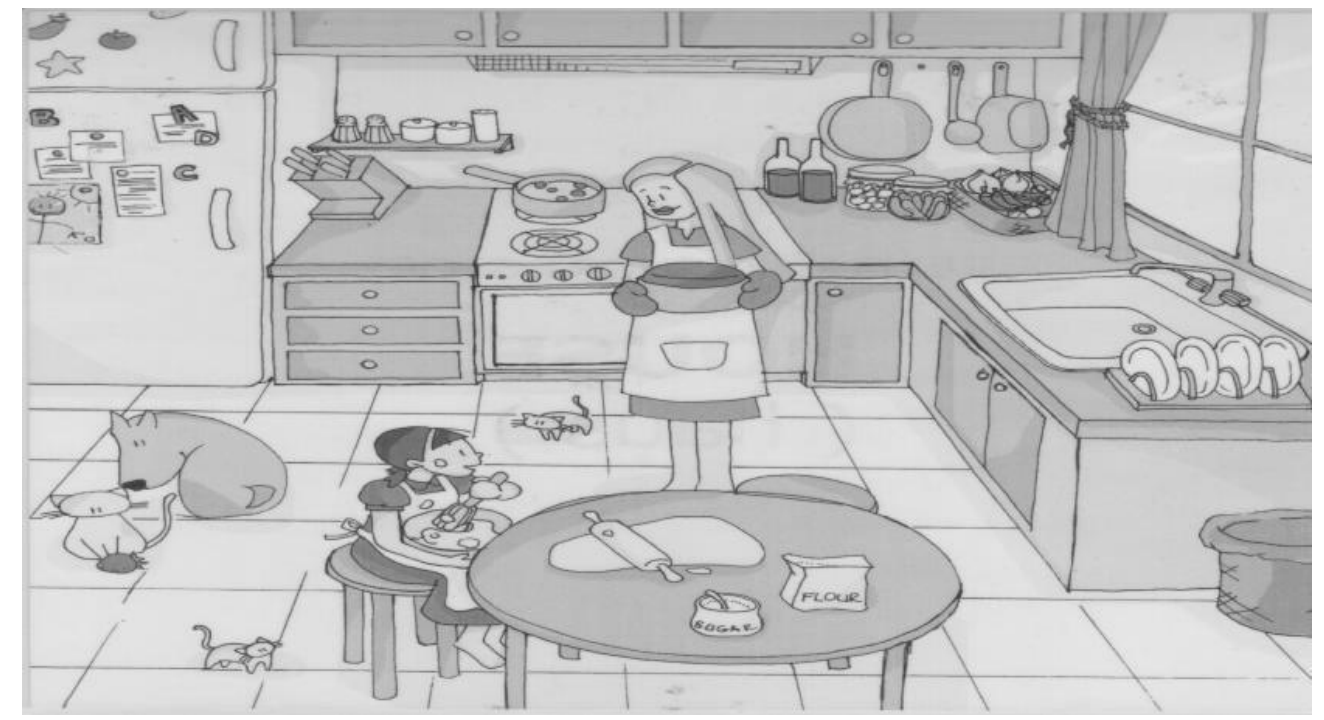




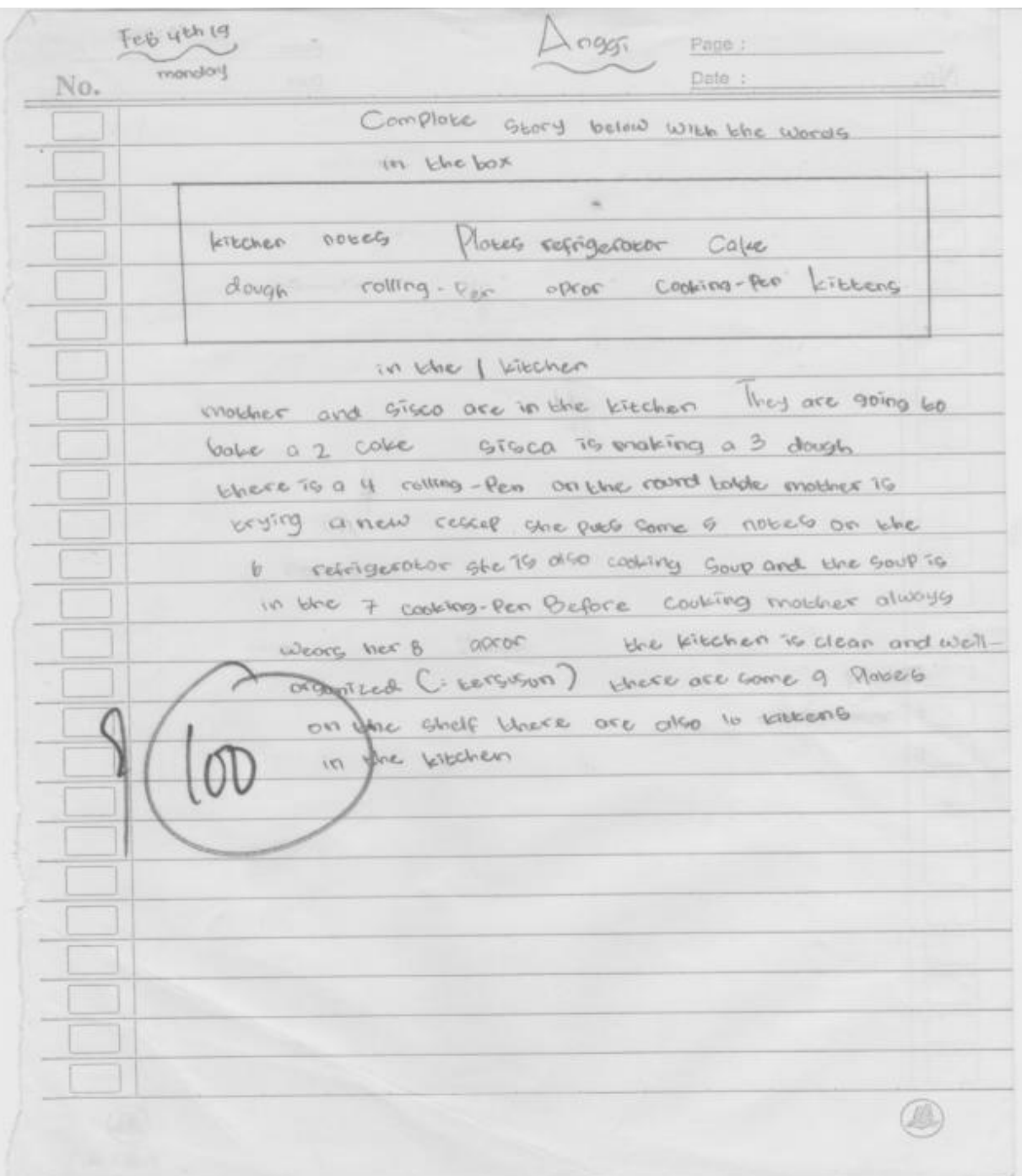

Figure 1

Anggi's Story 


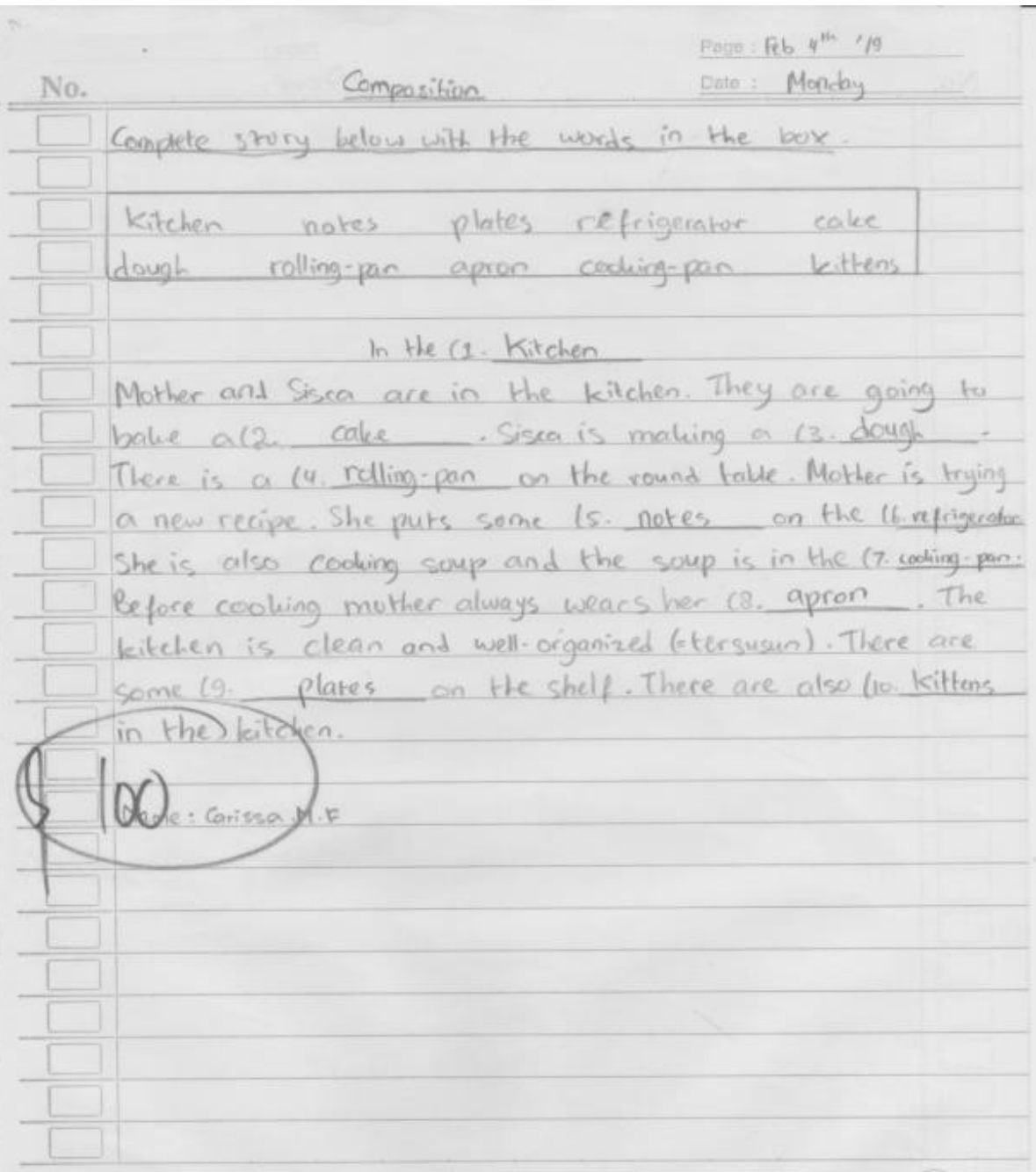

Figure 2

Carissa's Story 


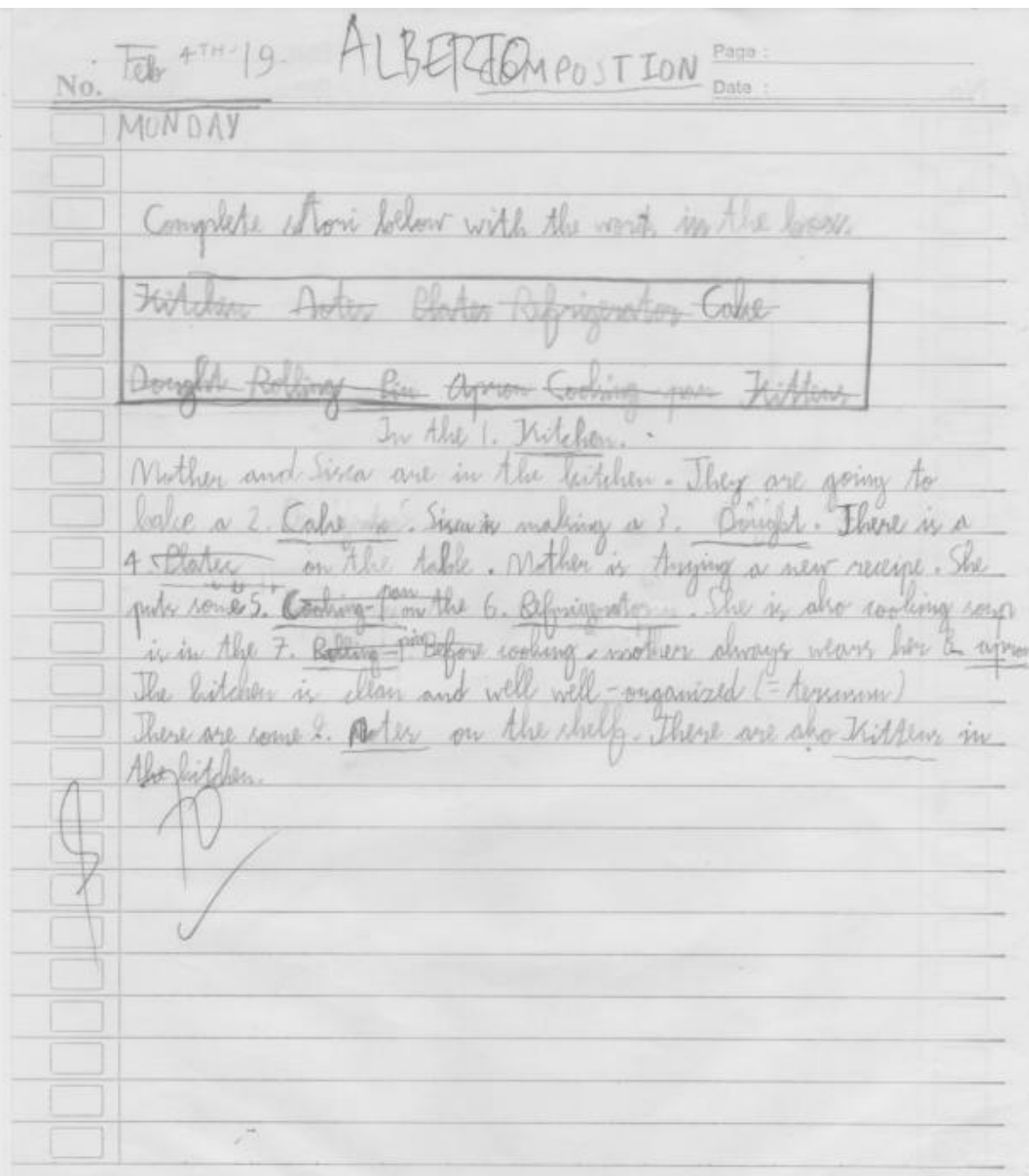

Figure 3

Alberto's Story 
Figure 4

Alfredo's Story 


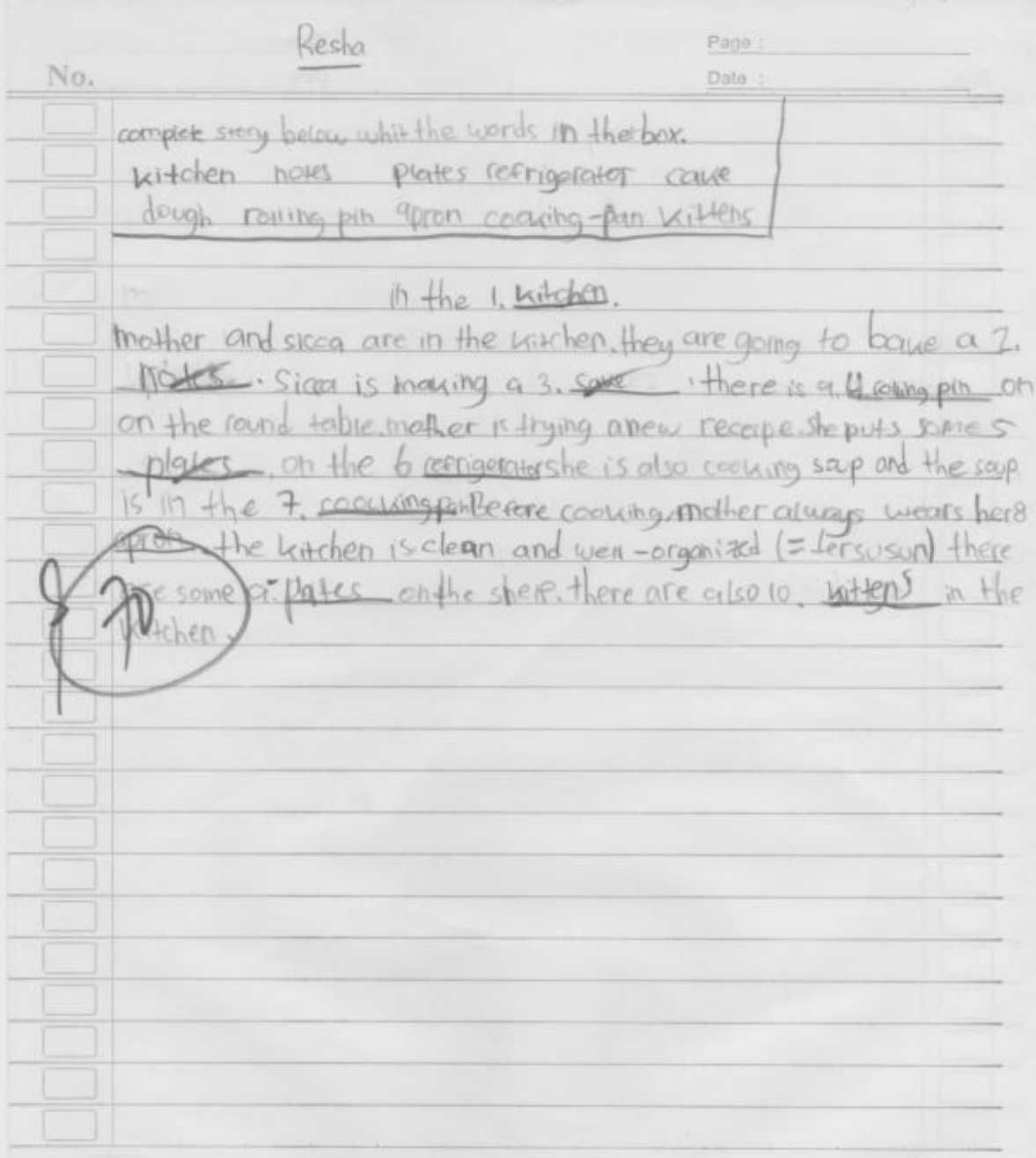

Figure 5

Resha's Story

Based on the results above, it can be concluded that not all the learners could make a story in written well. Some of them could not complete the missing words well. 


\section{In the Living Room}
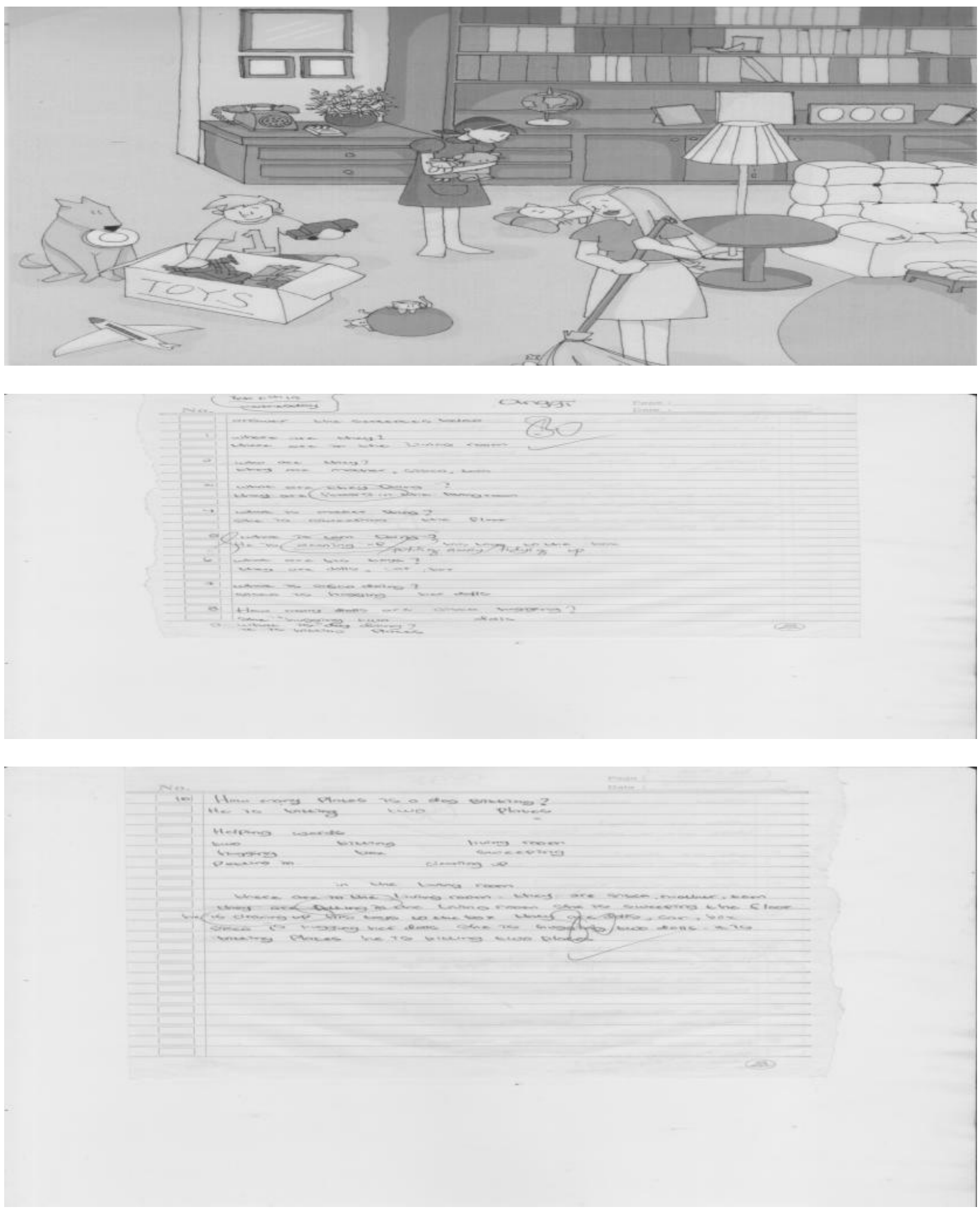

Figure 6

Anggis's Questions and Story 

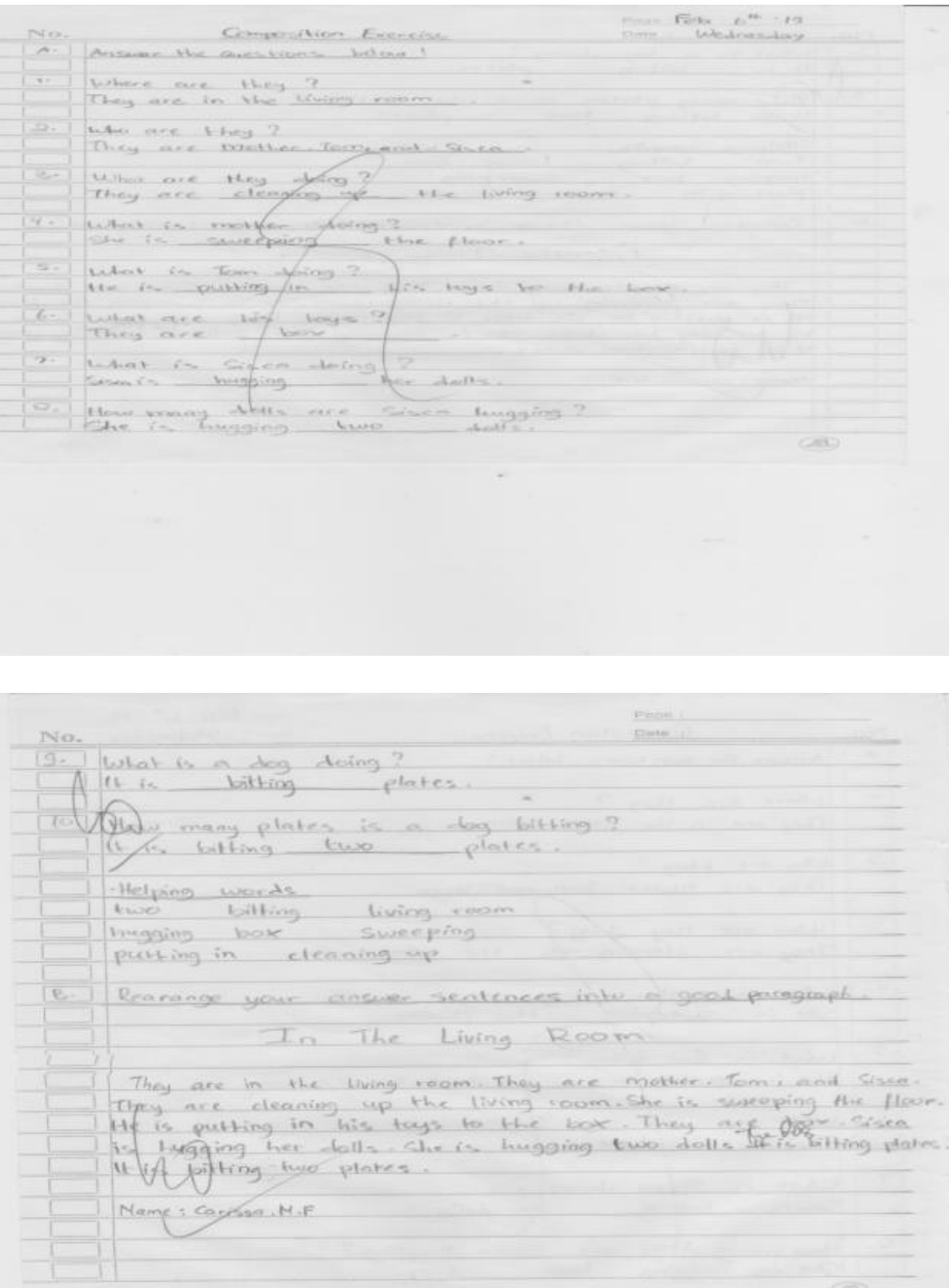

Figure 7

Carissa's Questions and Story 

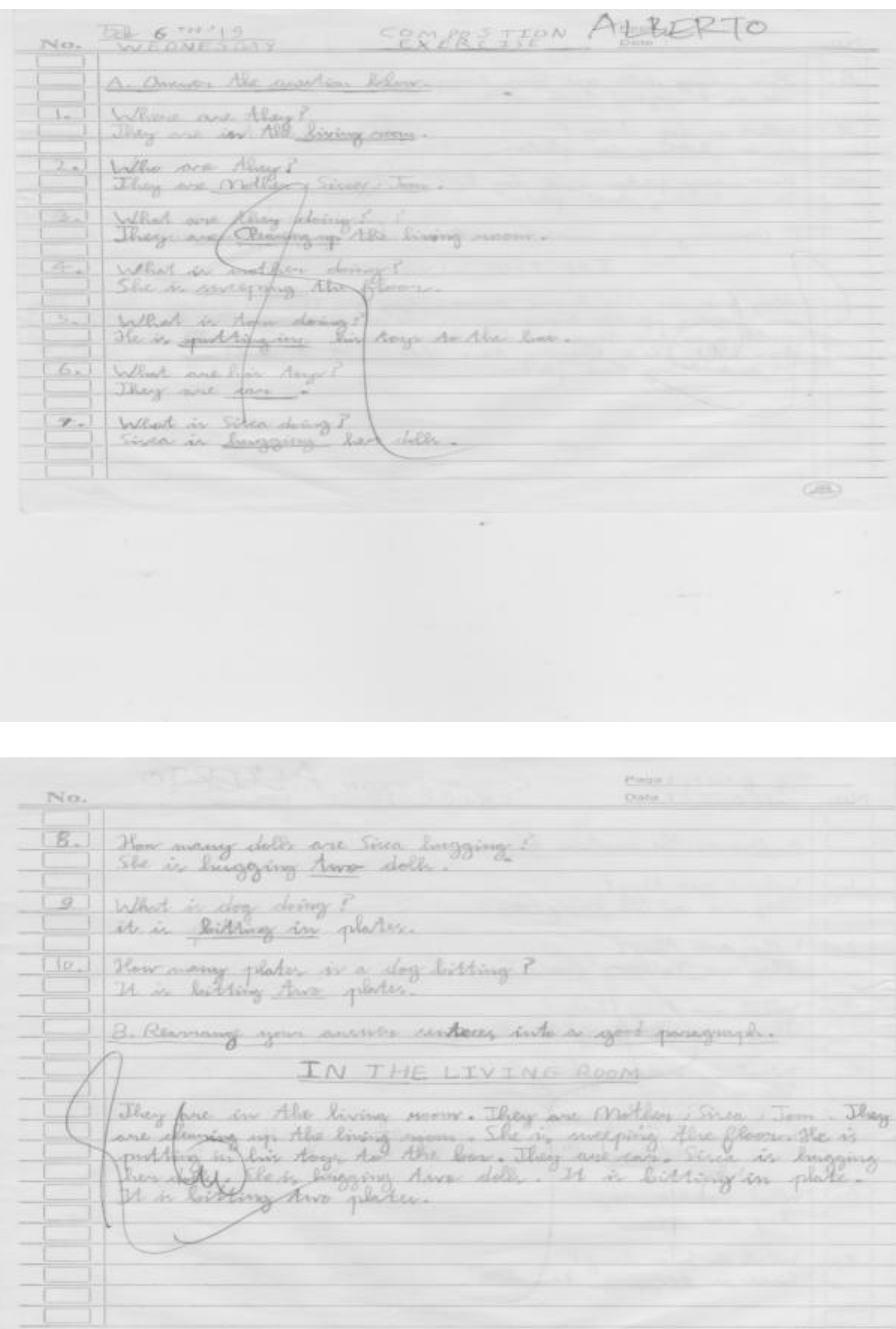

Figure 8

Alberto's Questions and Story 

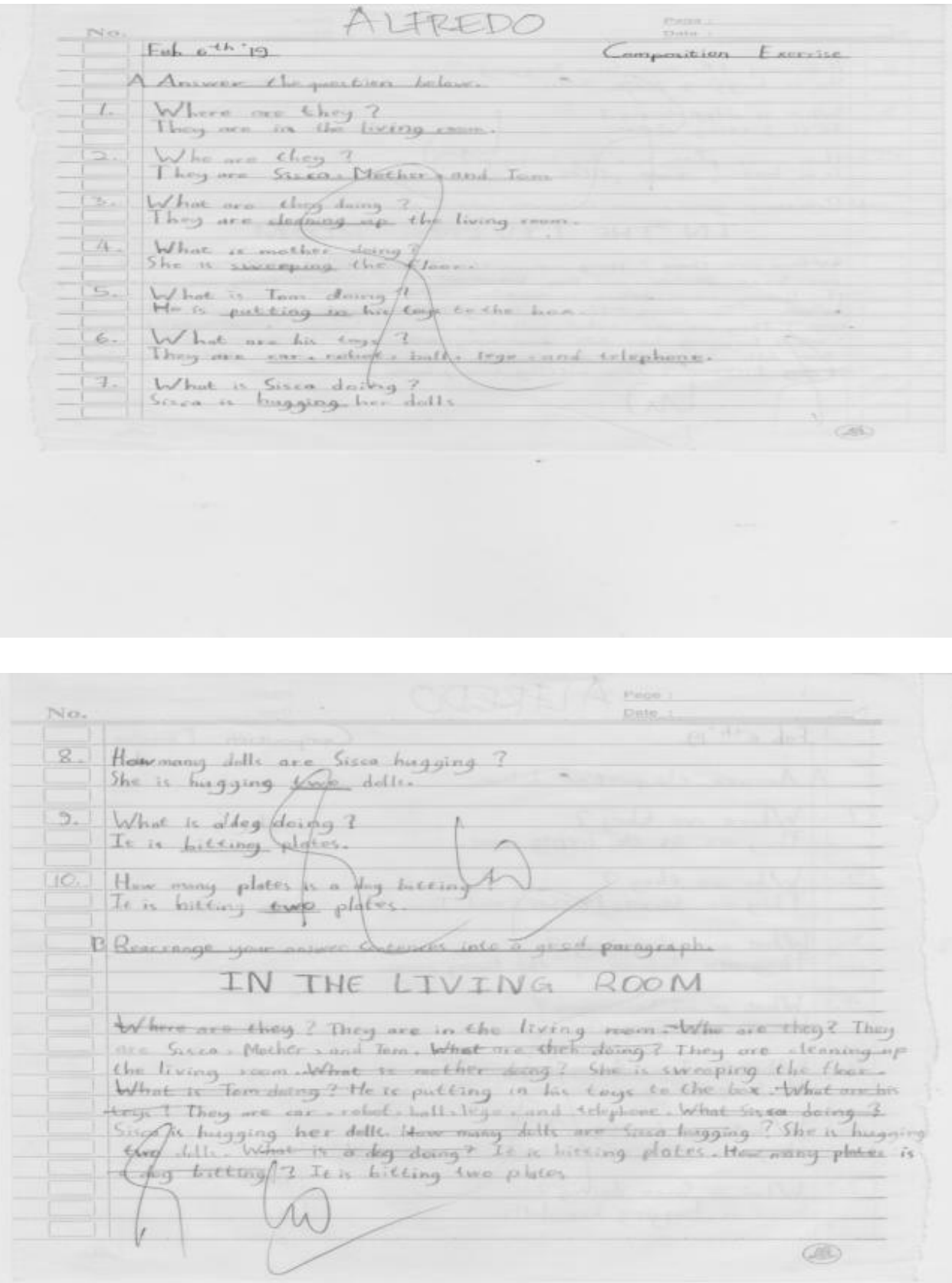

Figure 9

Alfredo's Questions and Story 


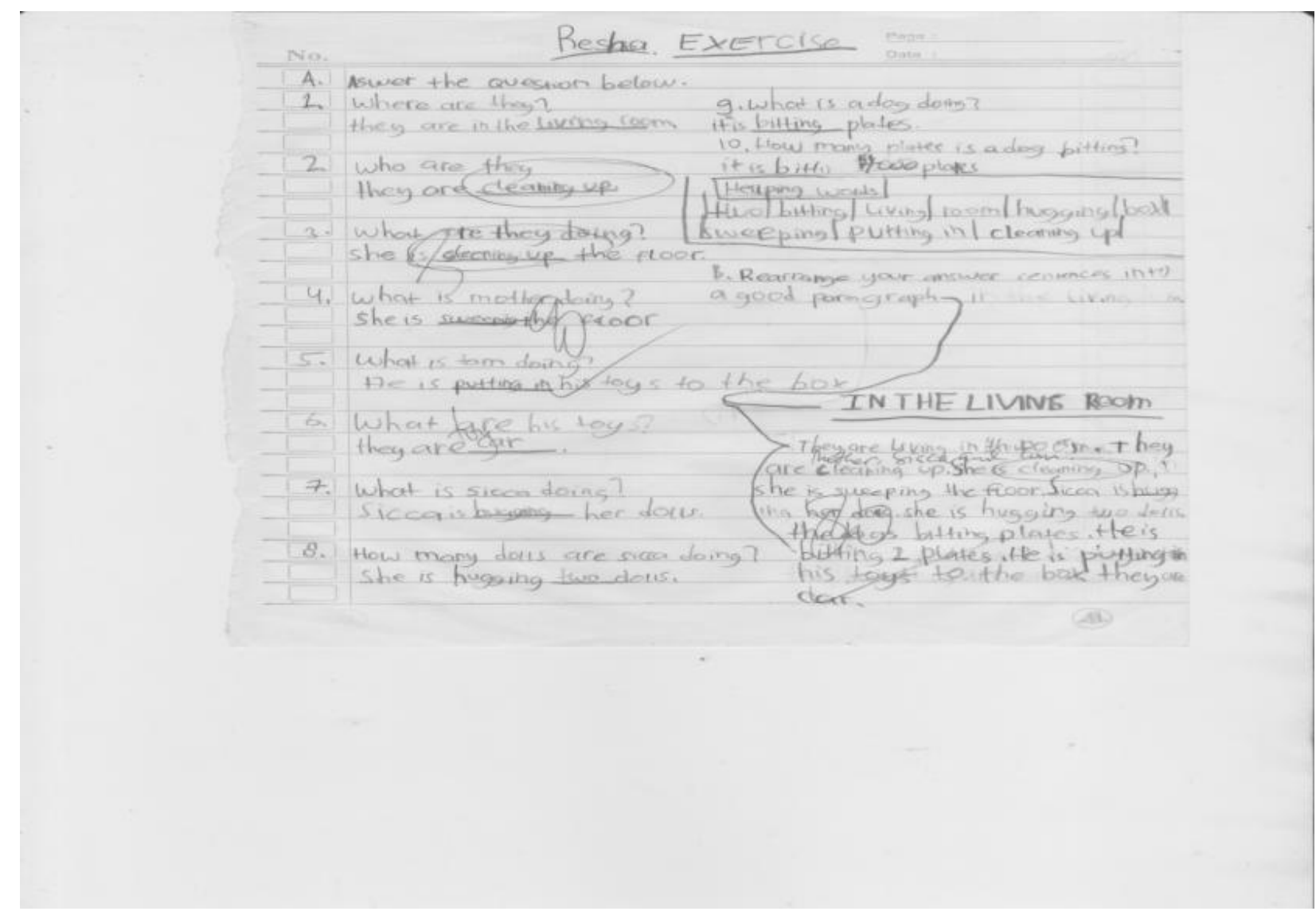

Figure 10

Resha's Story

There were 2 flashcards used to do the research. Both of them have questions related to the flashcards but the questions are in different form. The first flashcards were about completing the missing words and the missing words were provided in the box. Then, the second flashcards were about answering the questions. Next, after answering the questions, the learners were asked to arrange into a story which was still related to the flashcard.

The results were:

Figure 1 \& 6: Anggi's story. In the first flashcard, she could make a story well. She could complete the missing words given in the box, but in the second flashcard, she could not answer the questions and arrange the story well. The story was by arranging the answer sentences.

Figure $2 \& 7$ : Carissa's story. Both in the first and second flashcards, she could not only complete the missing words but also answer then arrange the answer sentences into a story as well.

Figure 3 \& 8: Alberto's story. In the first flashcard, he could not complete the missing words but in the second flashcard, he could not only answer the questions but also 
arrange the answer sentences well.

Figure 4 \& 9: Alfredo's story. He did the same as Alberto. In the first flashcard, he could not complete the missing words well. He made some errors. But in the second flashcard, he could not only answer but also arrange the story well.

Figure 5 \& 10: Resha's story. In the first flashcard, he could not complete the missing words well, but in the second flashcard, he made a little improvement. He could answer the questions then arranging them into a story.

Based on the results above, it can be summarized that most of the learners could make a story related to the flashcards well. Even when they were given and were asked to make a story with two types of making a story, the first type is about completing the missing words by using the words in the box and the second type is about answering the questions then arranging them into a story.

\section{CONCLUSION}

Based on the theories and research above, it can be summarized that writing is the most difficult part, among other English skills such as listening, speaking and reading, in learning English. Studying and learning English need the suitable way to be taught and understood. There are many ways of studying and learning English and flashcard is one of the teaching tools that can be used to teach and to improve the learners, especially EYL's English writing skill. Flashcards can also help the educators and teachers in teaching writing activity. There are also many ways of using flashcard to teach and to improve English skill. Flashcards can be used to teach and to improve listening, speaking, reading and also writing. It also can be used to study and to improve the learners' vocabulary, pronunciation, spelling, grammar, and so forth.

There are two types of using flashcards in this research, that is, to complete the missing words and to answer the questions then to arrange the answer sentences into a story. Different type has different result. In the first type, which is to complete the missing words, the learners, especially EYL could not complete the missing words well. It happened because some of them still did not know the meaning of the words well and they still got difficulties in putting the words into the correct sentence. The second type of using flashcard, the learners, especially EYL, started to show a significant improvement. They could answer then arrange the answer sentences into a story well. It could happen because before arranging the story, the learners have given the clues about making the story. They were asked to answer the questions given then arrange the answer sentences into a story.

\section{REFERENCES}

Arsyad, A. (2011). Media Pembelajaran. Jakarta: Raja Grafindo Persada.

Bourke, J. (2006). Designing a topicbased syllabus for young learners. ELT Journal, 60(3), 279-286.

Cameron, L. (2003). Challenges for ELT from the expansion in teaching children. ELT Journal, 57, 105-112.

Harmer, J. (2001). The Practice of English Language Teaching. 
England: Pearson Education Limited.

Izzan, A. (2009). Metodologi Pembelajaran Bahasa Inggris. Bandung: Humaniora.

Juhana. (2014). Teaching English to young learners: some points to be considered. Asian Journal of Education and E-Learning, 2(01), 43-46.

Permadi, D., \& Suryana, N. (2000). Pendekatan, Metode, Tehnik dan Model Pembelajaran Bahasa Inggris di SD dan MI. Bandung: Sarana Panca Karya.

Pinter, A. (2006). Teaching Young Language Learners. London: Oxford University Press.
Ron, W., \& Ardnt, V. (2011). Process Writing. London: Longman Group.

Slattery, M., \& Willis, J. (2001). English for Primary Teachers. London: Oxford University Press.

Susilana, R., \& Riyana, C. (2009). Media pembelajaran. Bandung: CV Wacana Prima.

Teng, F., \& He, F. (2015). An example of classroom practice using flashcards for young learners: preliminary indications for promoting autonomy. Studies in Self-Access Learning Journal, 6(4), 382-398. 